\title{
THE CHURCH AND THE CITY
}

\author{
J.J. Kritzinger 1 \\ University of Pretoria \\ PRETORIA
}

\begin{abstract}
One of the most important features of the late 20 th century is the phenomenal growth of cities. The whole urbanisation process is explained with special reference to South Africa, and its challenges for the mission of the church are outlined. The main areas of need of the urban and ubanising people are delineated, with the intention of stimulating a need orientated approach by the church. In a final section the future ministry of the church is summarised in three dimensions: the communication of the good news, the compassionate service ministry and the establishment of real koinonia.

Just as ubanisation may be called one of the most important forces shaping the last decades of the 20 h century, so the large city is an overwhelming fact of our time and that of our children. Although they are never separable, we should distinguish between the two aspects: the phenomenon of the city, and the process of urbanisation. Both aspects have implications for the life and ministry of the church.
\end{abstract}

\section{THE PHENOMENON: THE LARGE CITY}

\subsection{Something about the history of cities}

Since time immemorial people lived together in what would later become cities. The oldest walled cities date from 4000 or more years ago.

* Human beings are social and thus tend to congregate. In time the families living together would comprise tribes, and even nations.

- Sometimes the situation made it conducive or even necessary to live together. Primitive man lived in a hostile world where he had to fend for himself. Not only dangerous animals, but especially other groups could be kept at bay when the tribe was living and fighting together.

\footnotetext{
${ }^{1}$ Prof, Kritzinger is the Director of the Institute for Missiological Research at the University of Pretoria. The article is substantially the text of two talks delivered at the Baptist Missionary Department's National Conference.
} 
- That was the beginning of politics, the art of organising society. Cities thus had also a political origin.

* Religious factors were also important for the growth of the city, as was the case in Jerusalem as well as cities of the Far East. In Christian Europe the city of Rome was the first to express the majesty and honour of God in architectural terms, but later on a great number of other cities also erected magnificent cathedrals. In the shadow of these spires urban communities came into being.

- Economics, however, always was another factor. This can for instance be seen in North America where cities only started to grow when the western frontier was pushed to the coast and the available land became scarce. It is said that the countries with colonies did not show the same need to develop large cities - apart from the ports - because they had outlets for the population growth. In time the concentration of people also stimulated the different trades, with the result that the cities became the centres of commerce and industry.

\subsection{Size and growth of the city}

The size of today's world cities is amazing. Building technology made it possible for millions of people to be housed and to work in relative small areas.

- New York is maybe the prime example of the vertical growing city.

- Another type of city, epitomised by Los Angeles, has grown horizontally, but is kept together by an elaborate system of super highways, made possible by a relative affluence and an accompanying mobility.

- These examples are from the West. In the Third World a new kind of city sprang up. Apart from those sections within these cities - whether it is Bangkok or Manila, Lagos or Nairobi, Montevideo or Caracas - which are modelled on the Western cities, the Third World cities have millions of people (often the majority) living in informal or unofficial settlements unknown in the Western cities. And it is especially in these sectors of the cities where the growth is phenomenal.

David Barrett (see the following graph taken from his book World-class cities and world evangelization, 1986:8), the statistician and futurologist of the Christian movement, calls cities with over 'n million inhabitants "megacities". Those larger than 4 million are the "supercities", and the "supergiants" are inhabited by more than 10 million individuals each. 


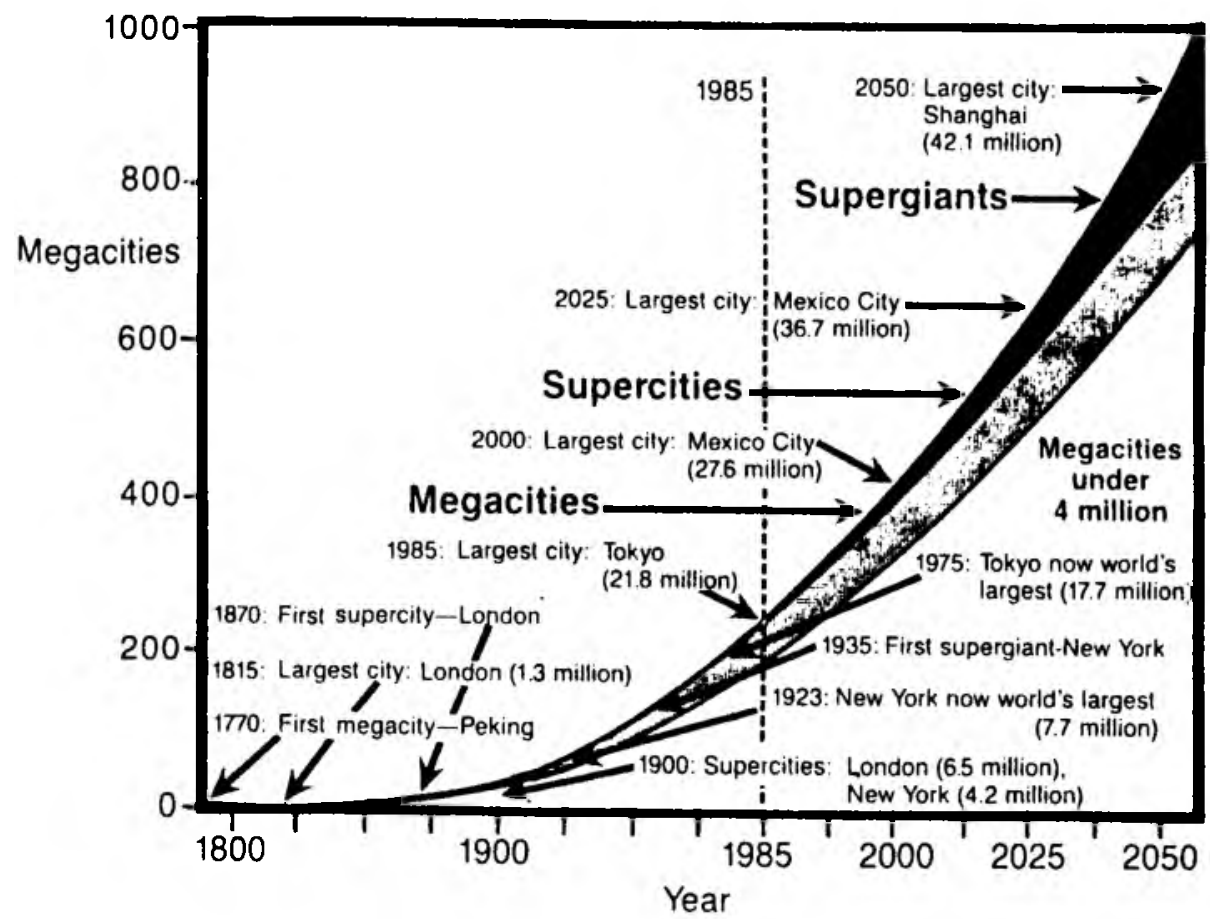

Graph 1. The World's Largest Citiés, AD 1770-2050.

Notes.

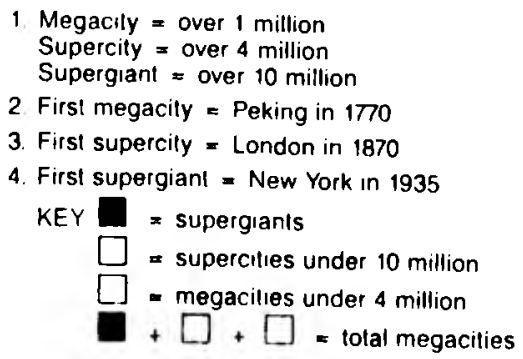


In 1770 Beijing (then known as Peking) was the first to become a megacity; London passed a million inhabitants in 1806 , but industrialisation stimulated its growth to such an extent that by 1815 it was the largest city with 1,3 million people. By 1870 it reached a 4 million and a new status (according to Barrett) of supercity. By 1900 the new star, New York, joined London in this club, but outgrew it and already in 1935 became the world's first supergiant of 10 million inhabitants.

In the second half of our century the Third World cities began to grow into the top ten. In 1950 there were seven cities with a population of more than 5 million, of which two were in the Third World. Today there are 34 such cities and 22 of them $(65 \%)$ are in the Third World (Linthicum, 1989:6). It is expected that by 2025 no less than 80 of the 93 cities with more than 5 million will be in Africa, Asia and Latin America (86\%).

By 1985 the 10 largest cities in the world were, according to Barrett (1986:45): Tokyo/Yokohama with a population of 21800000 ; Mexico City with 18400000 ; New York/NE New Jersey with 18300 000; Shanghai with 17500 000; Sao Paulo with 15 000 000; Beijing with 14600 000; Los Angeles/Long Beach with 10900000 ; Buenos Aires with 10800 000; Rio de Janeiro with 10400000 ; and Seoul with 10200000 inhabitants. Thus only two US cities were on this list, four in Asia, and four in Latin America, with none from Europe or Africa.

In 1988 Barrett (1988:1) changed his mind somewhat regarding Shanghai (which he earlier predicted will be the largest city by 2050), and expected the world's 10 largest cities in 2000 to be: Mexico City with 25820000 inhabitants, Sao Paulo with 23970 000, Tokyo/Yokohama 20220 000, Calcutta 16530 000, Bombay 16000 000, New York/NENJ 15780 000, Seoul 13770 000, Teheran 13580 000, Shanghai 13260000 and Jakarta with 13250000 . On this list only one Western city appears, and seven Asian cities (one in the Middle East), but Africa and Europe are still absent. (See also the following graphs taken from Bakke (1984), which differ somewhat from the above, but illustrate the case well.) Nevertheless, a megacity (larger than 1 million) is already large - and in 2000 there will be some 433 of these. Supercities (urban agglomerations with over 4 million inhabitants) will total 79 (59 of these in the developing countries) (Barrett, 1986:46). 


\section{The Global City}

By the year 2000 there will be 58 cities of over five million people compared with 29 today. Half the urban growth will fore from natural increase--the rest from people escaping boverty in the countryside.

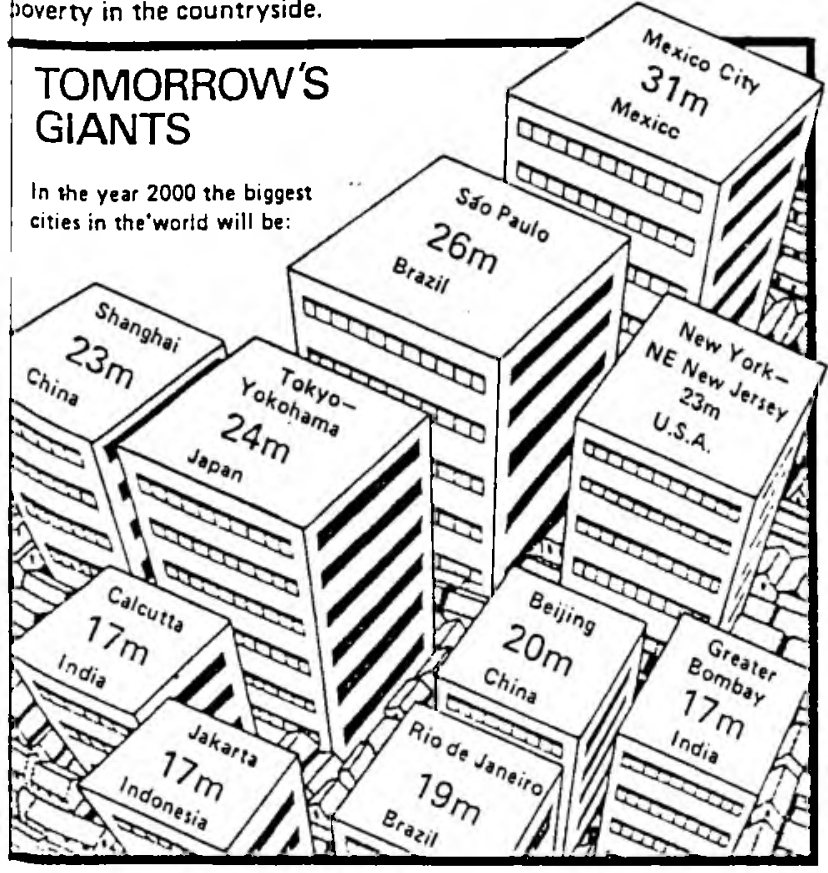

\section{REACHING THE LIMITS}

Around one billion people now live in Third World cities-a number that will double by the turn of the century and present an enormous challenge to city planners trying to cope with:

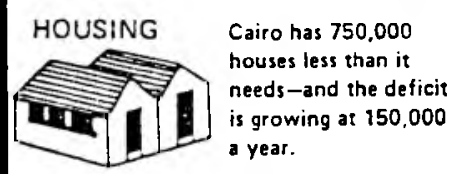

EMPLOYMENT Most city people workbut don't earn much. in Bogota the top 5\%
of city dwellers get $30 \%$

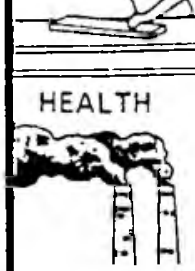
of the income.

\section{TRANSPORT Average traffic speed न-1 in Mexico is now half that in London or Paris.}

\subsection{The movement of people}

This implies a high rate of urbanisation. In 1800 a mere $1,7 \%$ of the world population lived in cities of more than 100000 inhabitants. In fact, only $3 \%$ lived in places having more than 5000 inhabitants. By $190014 \%$ of people could be called urban; by 1950 it 
was $28 \%$; and today it is well over $43 \%$; with an expected $51 \%$ in the year 2000 , increasing with 1,6 million a week. In the next 15 years another billion people will flee to these overcrowded cities (Linthicum, 1986:6). Until the end of the century it is likely that on average 1500 new residents will flock into Mexico City each day (Rubingh, 1987:369-379).

\subsection{The shift of balance}

Until 1975 the majority of urban dwellers lived in the so-called "developed" countries. By the year 2000 however the urban population of the developing nations will be twothirds of all the urban dwellers. In these cities the typical phenomenon is that of huge belts of squatter settlements encircling the original city. These informal settlements grow much faster than the other city sectors. Grigg (1987:15) quotes figures to the effect that from $19,6 \%$ (Bangkok) to $66 \%$ (Calcutta) of the large city populations live in squatter and slum areas.

The challenges of the city to the church will be dealt with later, but at this stage the statistical aspect is considered. Rubingh (1987) states that, in 1900, when only $14 \%$ of humankind lived in cities, already $29 \%$ of the Christians were urban dwellers, compared to only $5 \%$ of the non-Christians who lived in cities. The large cities were nominally "Christian" in those days, but not any longer. The largest cities are developing in traditionally non-Christian regions of the world, as can be seen in the following graphs, also taken from Barrett (1986:13).

It is unfortunate that world population growth today outstrips the growth of Christianity. Urbanisation is aggravating this situation and is moving the cities away from any previous identification it might have had with the Christian faith. 


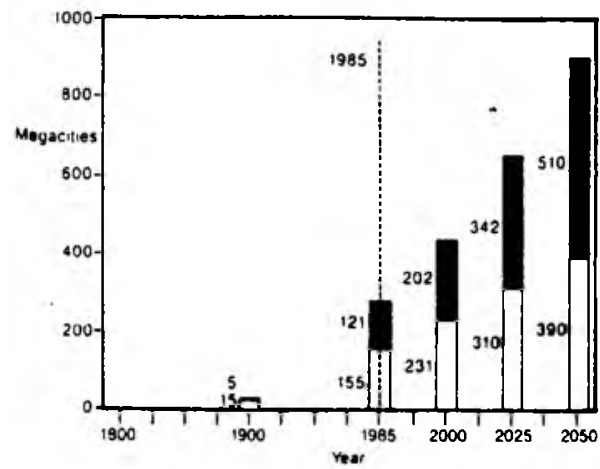

Graph 4. Non-Christian and Christian Megacities. AD $1800-2050$.

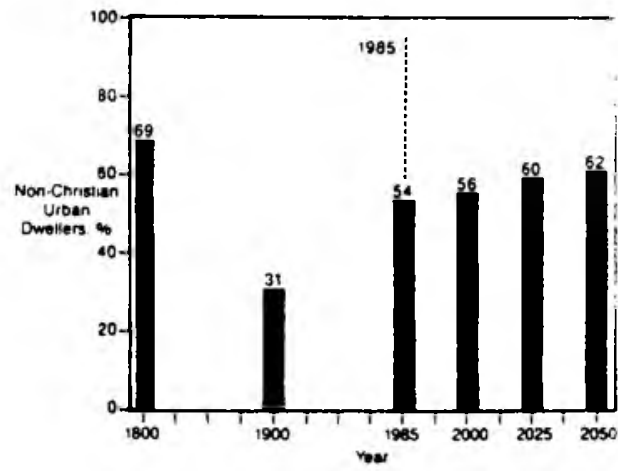

Groph 5. The Proportion of Non-Christians to all Urban Dwellers, AD 1800-2050.

\section{Notes.}

1. Non-Christian cities are those tradıtionally based on a non-Christian world religion, and now under 25\% Christian.

2 Christian cilies are those with long Christian Iradition and now over 25\% Christian.

3. Numbers are totais of enther non-Christian or Christtan cilies.

KEY: = non-Christian

- Christian cities

\section{The South African city}

Although the largest cities are not on African soil, this continent does have a sizeable number of cities topping a million in population. The largest is Cairo/Giza, but also South Africa has a number of cities. The PWV (Pretoria-Witwatersrand-Vaal Triangle) area may be regarded as a supercity, with a combined population of probably more than 7 million, but Johannesburg and greater Pretoria could qualify on their own as megas, as do Durban and the Cape Town complex. 
It is well known that in South Africa the urbanisation process of the White and Indian population has stabilised at about $90 \%$. Even the Coloured population already has a high level of urbanisation (almost $80 \%$ ). Thus the present and future growth of the cities will - apart from the natural biological increase - to a large extent be the result of the influx of Blacks from the rural areas. The case of Black urbanisation is therefore the important prozess to study.

Simkins (1985:45-46) estimates the 1980 Black urban population (including those urbanised within the homelands, and the homeland population on the city fringes) to have been $8,61 \mathrm{~m}$.llion ( $41,5 \%$ of the black population), but expects it to increase to 12 million (or $46 \%$ ) by 1990 , and 19 million ( $55 \%$ ) by 2000 - an increase of more than 10 million in 20 years! Where Soweto was the only black city with more than a million people in 1980 , there may he several in the year 2000 , depending on where the major urbanisation will take place.

The South African city is to a certain extent unique.

- Maybe the most visible aspect of its uniqueness is the strict segregation. Segregated neighbourhoods are general in the cities of the world, but not in such a systematic and constrained manner.

- Further: in the West and often in Third World cities the poorer neighbourhoods are in the inner city, and the usual movement of the middle class is towards the suburbs. But in South Africa the Blacks are more or less confined to the townships which are all situated on the outskirts at some distance from the city centres. Some townships in the vicinity of Pretoria, Durban and East London are even situated in other administrative areas (national states). Thus the poorest sectors of the population have to commute the longest distance to the city centre. It is ironic that many of the industrial work opportunities were later on established in the buffer zones between White and Black residential areas and so happened to be near, and in many cases next to the Black towns.

- The largest informal settlement areas (squatter camps) are also on the outskirts of cities, but mostly within homelands like Kwazulu and Bophuthatswana.

- What is further unique in South Africa is that these urban masses do not have freedom of movement. They are only allowed settlement rights within certain defined Group Areas. 


\section{THE PROCESS: URBANISATION}

\subsection{What causes urbanisation?}

There are two forms of urbanisation, which Fair (1985:1) (following Friedmann and others) calls "urbanisation-1" and "urbanisation-2". Urbanisation-1 is "the purely physical concentration of population and economic activities in towns and cities", and urbanisation-2 is "the social aspect of urbanisation as a way of life - becoming urbanised in a psychological sense". It can also be called "quantitative" and "qualitative" urbanisation. The one is the urban concentration, and the other the urban diffusion. It is clear that the church should be interested not only in the physical, but almost more so in the qualitative aspects of the urbanisation process.

Fair (1985:1) also introduces the four main interacting processes causing urbanisation:

- the economic factor of capital flows (investments) "which are the major engine of urban growth";

- the diffusion of modernisation which generates an urban ethos for the inhabitants, but has a much wider influence;

* the resulting rural-urban migration; and

* the "decision making and control on the part of those in power who can influence the rate and pattern of urbanisation".

We have already indicated the economic realities as the prime mover in this process. A simple model can illustrate it.
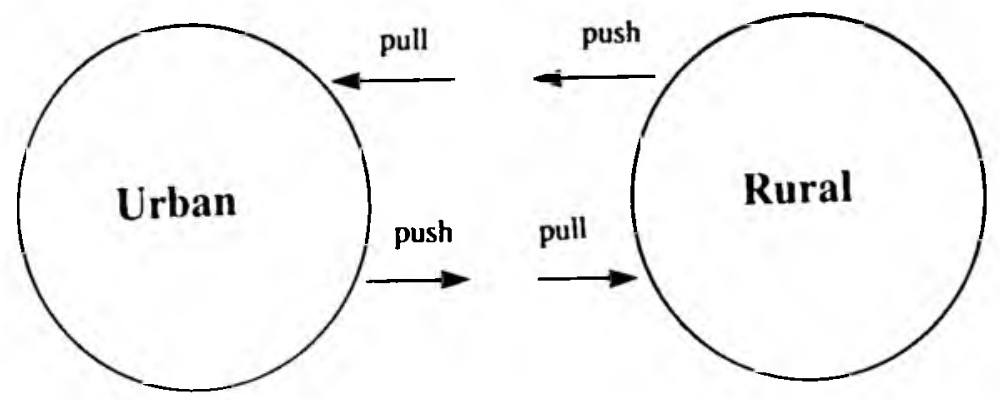
The people in the rural areas are subject to two economic forces: the push of the land which can no longer sustain them (which is generally the case in the peripheral areas of South Africa), and the pull of the economic opportunities in the cities (which, in the case of South Africa, is considerably more than in the rural areas). The combination of these push and pull forces are powerful enough to cause the migration to the urban areas. The counter forces are the (emotional) pull back to the traditional places and ways (which is not often strong enough to prevent movement, but may influence the permanence of the move), and the push which the city exerts on those it does not want to absorb (especially the influx control measures).

The growih of the older (Western) cities was especially stimulated by the pull effect of industrialisation. Dewar et al. (1984:79) indicate that the advent of capitalism has accelerated the movement of people to the cities. The "less developed" world, which the influence of capitalistic development reached only later, still has a much lower level of urbanisation than the West. It was calculated that in 1980 the average urbanisation level in the "less developed" world was $24 \%$, compared to the $50 \%$ for Europe.

Today the push factors from the overpopulated, underdeveloped and overexploited rural areas of the Third World do not only cause a higher influx of people to the cities of the Third World, but also a marked internationalisation of the Western cities to which many of these people from poor countries move.

\section{$2.2 \quad$ Influx control}

It is the fear of being swamped that causes virtually every Third World government, even while their countries are still relatively "under-urbanised", to attempt to curb the movement of people to towns and cities. The measures are usually a combination of coercive (stick) and incentive (carrot) methods.

In the light of this the South African infamous "influx control" measures were not as unique as was often supposed. They were also not unique in their failure to stem the tide. As the influx control system officially came to an end on the first of July 1986, we will not spend much time in describing and condemning it, but a few remarks about it will be necessary for the purpose of this article.

Lange (1979:129) calculated that in the late 1970s the decision of a homeland Black to emigrate to the (so called) White areas was quite rational in economic terms. As a 
matter of fact, he indicated that it would remain gainful even though the said Black's chance to find employment would be only fifty-fifty, even if he risked arrest and imprisonment for excessive periods (Lange, 1979:133)! Migration to the metropolitan areas provided the best alternative. That is the main reason why the control system known as the "Pass laws" could not work - just as the sand castle on the beach never can stem the tide - the pressure of needs were just too great.

The influx control system came in force in the 1920s, even though aspects of it (especially the compound) originated with the earliest diamond and gold mines. In 1922 the Stallard Commission formulated the principle which for many years were operative in the law, and well summarised the general view of Whites:

The natives should only be allowed to enter urban areas which are essentially the white man's creation, when they are willing to enter and to minister to the needs of the white man, and should depart therefrom when he ccases so to minister ..."

The Black (Urban Areas) Consolidation Act No. 25 of 1945 became the main piece of legislation controlling Black urbanisation. It defined "prescribed areas", and, in Section 10, declared which Blacks were allowed to be and to live in the "prescribed areas". People who could not immediately prove to anyone confronting them (by showing their "passes" with the necessary "tjaps"), that they were legally present, were arrested and deported. In such a way thousands of "redundant, idle and undesirable" Blacks were removed to their places of origin "or the territory of the national unit where they fit in ethnically if they were not born or bred in the homeland" (General circular no. 26 of 1986 of the relevant Department).

Quite apart from the utter immorality of this kind of approach, the immense suffering it inflicted on people, and the injustice of it all, these controls only succeeded in slowing the inevitable process and stifling the positive forces that could have brought much development in the cities and especially Black city life. It also contributed significantly to the breakdown of not only the image of the servants of the law who were seen to be (only) the perpetrators of the harshest aspects of apartheid, but also the discrediting of all official structures. In the process situations were caused in the Black townships which would alienate a whole generation and lead among other things also to the breakdown of family life.

Fortunately this policy is something of the past, but its horrible shadow still lingers in the form of its results. The results are physical deteriorated towns, but also a pervasive negative mentality in the communities. 


\subsection{The future of the South African city}

The urgent question - also for the church in its mission - is: what about the future? Ann Bernstein (1989:65-71) of the Urban Foundation writes perceptively about "a new national agenda". She recognises four aspects which still complicate the urbanisation process: the history of racially discriminatory legislation; the backlog of deliberate decline in urban conditions; the relatively large numbers of people involved in the process; and the fact that the people who are now urbanising do not have the franchise (Bernstein, 1989:65). According to Bernstein the development of a new urbanisation strategy will entail movement on three related levels, which should all be addressed.

On the first level solutions should be found that would lead towards real freedom of movement for all South Africans. Although the government's new policy gave a measure of freedom to some 14 million Black South Africans, there are 6 to 9 million TBVC (Transkei-Bophuthatswana-Venda-Ciskei) citizens who are currently still in a position of considerable uncertainty (Bernstein, 1989:67) - that is quite apart from the far reaching constraints of the Group Areas Act.

On the second level the important question of where and how Black urbanisation should occur would have to be addressed. The apartheid influx control measures have not been able to prevent urbanisation, but did succeed to "distort its form, influence its location and disguise its magnitude" (Bernstein, 1989:67). Unfortunately, some of those policies and pre-1986 mindsets are still in place, and may hinder further developments. Some of these are:

- The feeling that the existing metropolitan areas are already too crowded and further Black influx should be restricted.

Bernstein (1989:69) feels that here a major conceptual breakthrough is necessary:

"Since the early 1980 s there has been a significant shift in how the international community views large cities. It is now recognized that policies to divert growth away from the large cities have almost universally failed and that the cities of the Third World have coped considerably belter than was initially anticipated. South African cities are small by international standard and should be allowed to expand. Attention should focus on how best to manage these urban centres rather than on curbing their expansion."

- A second factor is the reluctance to promote the access to land and serviced sites for informal settlements. 
To this Bernstein (ibid) says:

"Informal sctulement must be recognised as an efficient, affordable and prolific form of housing. The thrust of public policy must be towards the preservation and upgrading of all forms of shelter and not their demolition..." (For an analysis of this problem, see the recent article of De Becr, 1989.)

- A third problem to Bernstein was that government was still thinking in racial terms.

Urban policy should above all be challenged to succeed in things like the following: the provision of access to employment, shelter and other urban services to the mass of urbanising people; the ensurance that the poorer sections of the community are increasingly incorporated into the urban system; and also the political legitimacy of the management of the cities. These things are continually bedevilled by the insistence to continue thinking in racial terms.

On the third level attention would have to be given to the fundamental question of the ownership of the city; who decides on urbanisation policy? Whose city is this? Who is planning for the city and who do they represent? What is our guiding image of the city? The first hurdle is already cleared: the Blacks - as was always the case with the other population groups - are accepted as permanent inhabitants of the cities. There is however no way to evade the issue of political rights. There can be no solution to the urban problems without this basic issue being addressed satisfactorily.

It is clear that this kind of an agenda for the future of the cities of South Africa will have to be dealt with also by the church in its ministry.

\section{TIIE NEEDS OF URBANISING AND URBANISIED PEOPLE}

\subsection{The need orientated approach}

The church should adopt a need orientated approach in its mission. The church too glibly presents Christ as the answer, without posing the real questions! Being obedient to the call of God precludes the possibility to work as if the people and their circumstances are of no importance, as if people do not matter, but only souls. The gospel has to do with the whole human being in context. We are the witnesses of Him who gave his life for people. He was not a Crusader for a cause, but the Saviour of people! 
When dealing with the church and its mission in the cities, it is therefore of the utmost importance that we focus on the needs of the urban and urbanising people. It is true that there are a wide spectrum of urban sitations. The mission task in the present and future South Africa is dealt with in Kritzinger (1989) (also see Kritzinger, 1988:171). The following communities may be mentioned:

* New concentrations and resettlement towns in rural regions (like Dimbaza in Ciskei, Winterveld in Bophuthatswana, and hundreds more).

* Communities of migrant labourers in cities (and their families).

* Commuting communities (in the vicinity of cities and larger towns).

- Minority groups - in terms of religion, ethnic origins and language - in cities.

- New towns (like Botshabelo near Bloemfontein, the concentrations of KwaNdebele, and informal settlements like Mitchell's Plain, Crossroads and Khayelitsha on the Cape Flats).

- Urban group areas (especially Black and Coloured townships).

* White suburban communities.

- Urban subcultures (especially in the city centres).

Each of these communities has its unique combination of needs, which will differ from the other, but their specific needs should be taken as points of departure.

\subsection{Existential needs}

The physical needs are apparent and overwhelming - for anyone observant enough to see. Millions and millions of people descend on the Third World cities, most of them refugees from their past. Many are already weak and impoverished by the struggle to survive in the rural area. Others come with dreams in their eyes, young people in search of a better life in the city, but what do they find? More than often they land in the slums, squatter areas, favelas, barrios or bustees, whatever they are called. Unfortunate experience shows that the majority of the new arrivals will stay in these squatter areas indefinitely. It usually turns out to be not a temporary halfway station to the top, but the terminus of the road.

Calcutta is one such example:

\footnotetext{
"More than 8 million refugees have fied to Calcutta in the past 20 years. More than onc-half million of them sleep, cat, care for their children, make love, bathe, run makeshift shops and live their entire lives on the streets for everyone to see ..." (Linthicum, 1989;6).
} 
Yes, the needs of the poor are basic things like food, shelter, clothes. To millions even these are not available. The very same girls with the dreams in their eyes will have to sell their bodies in order to live! Eventually even thieving becomes an industry, as is begging. The 50000 people living on the refuse-heap of Manila - called Smokey Mountain - are lucky, because they have a place to scavenge for edibles as well as recycleable materials, even further materials to upgrade their shelters!

In South Africa such urbanising poor are increasingly found; poor people who lack the most basic necessities of life. The Black housing shortage is currently estimated at anything from 342000 in the "White-designated areas" (others think it is nearer 832 000 ) to a total of 1,4 million. The figure for Soweto is 36000 , Katlehong (East Rand) 30000 and Ibhayi (PE) 25000 . A conservative estimate of the number of Black squatters is 1,7 million. The backlog for Coloured housing is 100000 . (All these figures from the Race Relation Survey 1987/88, pages 197-199.) South African cities are increasingly assuming the appearance of other African cities: a well planned and serviced core surrounded by haphazardly built, unplanned and often illegal squatter or informal settlements.

Quite apart from the physical backlog in housing the aspect of ownership also gives cause for worry. It is commendable that the government has at long last made it possible for Blacks to own and build their own homes. Unfortunately only about $6 \%$ of Blacks can afford the R40 000 ownership bond from the government. According to De Vos (quoted by De Beer, 1989:79) no less than 56\% of the Black population cannot afford, without being subsidised, a "standard" house of R20 000 - only about $17 \%$ can afford it. A further $27 \%$ may afford this house, but with the aid of subsidies. Nevertheless, of the amount of R750 million spent on housing in 1988, $40 \%$ was spent on houses costing more than R40 000 and only $25 \%$ on houses valued below R15 000 . And it is actually in the price bracket of R10000 and less where the greatest need is to be found (Henning, 1989:13)! Mashile (1985:82) notes for Soweto, as an example:

"It is apparent that Black attitudes and opinions as expressed in Soweto reveal a conflict with the
urbanisation policics pursued by the present South African White Government. Undoubtedly
this dissatisfaction with the living space in Soweto is a potential sourec of conflict."

\subsection{Total necds}

It is important that we look deeply into the needs of the urban poor, and do something about it, but there is something that we not must forget. Viv Grigg (1987:15), who left 
everything behind and went to live in a slum in Manila in order to reach out to those poor, complains about the absence of the church in the slums of the Third World cities:

"I don't mean that there are no relief and development agencies. They are many, and most are doing good work in their defined diaconal roles. But the church has given the poor bread and kept the bread of life for the middle class" (his emphasis).

It is necessary that we have a much deeper understanding of the needs of urban dwellers. We should not overreact to the danger of forgetting the socio-economic needs in such a way that we now once again start to forget the whole person by ignoring the more spiritual needs.

It may be helpful to keep in mind the areas of need which Ellison (1987:36) spells out:

* The spiriturl/moral area, such as the training of their children, their drawing closer to Got, the finding of forgiveness, and purpose in life.

- The social/cmotional needs like loneliness, internal and interpersonal conflict, marital difficulties, parenting difficulties, depression, substance abuse, homosexual and cther sexual problems, threatening suicide, grief, divorce recovery, stress and anxiety.

- The cognitive aspect: basic intellectual abilities, career guidance, and second language acquisition.

- The physical needs like food and nutrition, shelter, clothing, health care, safety, and the improvement of the quality of life.

It would be a tragedy if 'we do not take notice of the biblical message that Liberation Theology rediscovered and impressed on us: God has an intensive interest in the wellbeing of the poor, the widows, the orphans and the foreigners - those who are at the receiving end of the suffering and injustice in the world, and He expects his church to live up to this same priority. We should have compassion for the poor in the cities, and spend ourselves in working for justice. But we must have compassion for man in his totality. We should act on a holistic understanding of the needs of the city - also the spiritual, mental, psychological and emotional needs should be taken into account. The above list could help us to keep the whole spectrum of needs in mind. It would really be worthwhile to work through the list for every subgroup in our cities, in order to identify the prio:ity needs, so that we may act in relevant ways. 


\section{THE CHURCH AND THE CITY}

\subsection{A reorientation towards the city}

Viv Grigg (1987:22) makes a surprising, but true observation - while he applauds the latest missionary initiatives in which the unreached peoples are being reached, and missionaries being recruited for "frontier mission", he reminds missionary planners: "Sorry, the frontier has moved!" There seems to be an almost exclusive focus on the unreached tribals of remote places. The movement of these people has, however resulted in the real frontiers having shifted to the cities.

Yet, even while more and more mission executives say this in public, in practice there are very few missionaries and mission organisations that seem to be serious about the city. Why? Greenway (1989b:6) makes the sour comment:

"Why do crowded quarters, traffic congestion, noise, the prevalence of crime, and the hectic pace of urban life make the city too hard 10 bear, while rural missionaries in the past and present are willing to sacrifice themselves unstintingly for relatively smaller numbers of people?*

The church has been notorious in abandoning the city centres. In North America "the suburban flight" came into full swing when the poorer (and Black) sector of the society began moving into the city centres. Someone said, tongue in cheek (Conn, 1984:134), that

"integration is a honky term to cover the period of time between the moving in of the first black and the moving out of the last white".

Churches have withdrawn socially from cities by migration, says Greenway (1989b), but their leaders have done it theologically by professional and scholarly neglect.

Instead of facing the challenges of the new frontiers of urbanisation and industrialisation,

"her (the church's) face is often turned with nostalgia towards the garden (where man's journey began) rather than toward the City, the New Jerusalem (the Christian destiny, the eschatological focus of man's journey)..." (Rubingh, 1987:370).

It is interesting that this rural mindset predominates to such an extent, because Christianity was and is very much an urban religion. With some $43 \%$ of the world population living in cities, no less than $62 \%$ of Christians are already urbanised, compared to the $24 \%$ in the case of non-Christians (Rubingh, 1987:371). Why then this negative view? 
The city was not always viewed negatively, says Harvie Conn (1984:127). He illustrates it with some terms from the English language which came from the Latin and Greek words for "city":

".. we city dwellers ... werc supposed to be more civil in our manners and more civilised in our ways... From ancient Latin we have borrowed the word urbs which also meant city, and we used it to create the word uroane which describes smooth manners ... And from the Greck polis,city, we inherited our word politic. If you are politic, you are expedient, shrewd, discrect, and artful in your address and in your procedure ..."

It was some time during the nineteenth century that this almost anti-rural attitude was reversed into something like a modern myth: urban life was seen as dehumanising; the city became a symbol of social disorder and artificiality, anomie and chaos ... and, like all myths, it became very difficult to dispel. Reason found it impossible, because it so happened that the beginnings of the sciences of sociology and cultural anthropology coincided with the mythical turn against the city, and these "scientists" accordingly found the "scientific" evidence to reinforce a perception of the city which, although it was not without substance, was not the whole truth about the city.

Conn (1985a; 1985b and 1986) sets himself the task of dispelling this myth. In a series of scholarly articles he addressed aspects of this. He informs the reader that contemporary scholarship is already beginning to warn against this rural-urban polarisation, because almost every community is already "urbanised" (remember the definition of "urbanisation-2"), the one only more than the other. He asks a series of penetrating questions:

* Have we read assumptions into our observations? Are we not blinded by our middle-class cultural expectations and perceptions?

* To what extent is the migrant uprooted? It is found that the migrants to cities usually do not leave their family structures behind. As a matter of fact - the presence of relatives in the city may be a prime motivation in moving there.

- What is the degree of loneliness in the crowd? Some urbanites actually moved to the city to fird a cure for their loneliness amid the traditional relationships forced on them.

- Does the city really cripple personal wellbeing? Often people from the working class view their situation quite differently and may find city neighbourhoods vibrant with communal spirit and vitality, although others may view it as degrading.

- Is the city more dehumanising than the country? The answer given by millions is: no. 
The city is not heaven on earth; neither is it hell itself! It is necessary that the church should arrive at a more balanced view of the city. Part of this balanced view is a change of attitude. Rubingh (1987:379) finds signs of this happening, not least through the contribution of people like Conn and Greenway who put much academic effort into it (and even started seminary programmes, as well as a periodical called Urban Mission). Greenway $(1989 \mathrm{a}: 13,16)$ has some practical advice on how to change this attitude. The first thing the churches and denominations should do is to start a programme to "see, learn and love" the city and its people. There is a certain "invisibility" of the city to the church and its ministry.

The beginning of a Christian responsc to the poor in the city, therefore, has to take the form of
planned visits, the development of trust relationships, the exchange of ministries and resources,
and growing demonstrations of Christian love ... cvery suburban or small town church should
make a long-term commitment to building meaningful relationships with some church in a poor
city neighbourhood."

This should start with the leadership. He quotes a certain Oostdyk who predicted:

"If every Christian scholar, student and preacher spent just one month living among the poor, no church or school would cver be the same. Ministrics would be changed overnight. The neighbourhoods of the poor would be changed, $100 .$.

The relevance of these remarks to the South African church is very apparent.

\subsection{The church's presence in the city}

In the 1960 s there was a serious debate on the concept of Christian presence. Some missiologists thought it unnecessary to "name the Name" among non-Christians, but thought that the mere presence of Christians would be enough of a witness. There were also talk of "the anonymous Christian" and "Christus extra muros ecclesiae". We believe that the communication of the gospel is an essential dimension of mission, but it is true that there is a sense in which Christian presence is the most basic form of mission. A Christian must be present before he/she can be a witness. That is exactly what Jesus did when He was born a human being, and a poor one at that. He came to be present with the people where the needs were. Viv Grigg (1987:17) says - and his own ministry gives credibility to this: 
"A life lived among the poor as one of them is the key to a movement. That is part of what Jesus was talking about when he discussed grains of wheat."

What we are speaking of is called incarnational mission. There are different models currently used in the outreach to the urban poor, but the successful ones seem to have the incarnational element built in. They do make use of outsiders, but in such a way that they live as catalysts among the people, opening up models of ministry (service) to the local Christians.

-It appears from the available data that the extent of incarnational modelling and pastoral lcadership from within the communities determines whether the church will be established" (Grigg, 1987:20).

This kind of sacrifice seems to be asking too much of middle-class Christianity, however, says Conn (1984:133). He finds that the materialistic ideals and lifestyle are taking the relatively affluent captive. That is why urban mission challenges the comfortable middle class church to an introspection: to what extent were these ideals and values confused with Christian principles?

The baptism of materialism in the name of Jesus, the benediction of competition as a way of life, the sanctification of growth as numerical success - all of these hinder from finding the invisible, urban poor and relating evangelism to 'the underside of history'."

On the one hand the church has to challenge all people at all levels of society, as it has already so aptly been put, "to live simply so that others may simply live"! That should be a basic motivation for all Christians. Still, there is also another aspect.

"But we must also hold out to our people the further call of Jesus for many to take up an apostolic lifestyle of identification with the poor in order that the poor people's church may be established" (Grigg, 1987:21).

We must rediscover, and return to the pattern of Jesus, who had the lifestyle which can be called "non-destitute poverty". He was poor, as He came to be with the poor. Thus He communicated the good news to the poor not as one who was an "outsider", who knew nothing of their struggles and needs. He nevertheless represented the "outside", without which these people could not be saved.

In the same way we can argue that missionaries (outsiders) are needed as "change agents", but only those with appropriate lifestyles. As Grigg (1987:22) puts it:

"A missionary living on $\$ 2800$ per month in an American-stylc house, sending his children to an American-style school, trying to reach people who live on $\$ 200$ per year, is like a B-52 bomber attacking gucrillas." 
John M. Perkins consequently speaks of the "three R's" for the church in the city: reconciliation (between the rich and the poor), relocation (physical presence where the ministry is needed), and redistribution (of resources). Evangelism in the city involves compassion and restructuring - a real presence.

\subsection{Ministering in the city}

A diversity of structures ...

There is not only one way for the church to deal with the city. Ray Bakke (1984:151152) the urban specialist for the Lausanne Movement, counted at least sixteen common contemporary urban mission and evangelism strategies he found in the course of his efforts to network people and churches which are targetting the city. He could also identify seventeen types or models of churches in the cities: the Cathedral, the denominational mission, the exethnic church, the house church, the immigrant church, the intentional community church, the international church, the migrant church, the multilanguage cluster church, the old First Church, the new style church, the parish church, the sectarian church, the storefront church, the super church, the task church, the university chapel (ibid: 152-153). There are many ways the churches are going about, some with more relevance than others, but there are some basic dimensions to the ministry.

\section{... but a unity of purpose}

It can be said that all faithful ministry in the city (as elsewhere) should have the honour of God as fundamental purpose. This can only be sought in obedience to the missionary example of Jesus and the leading of the Holy Spirit. At least three dimensions of this obedience can be indicated.

\section{Kerygma}

The first dimension of a missionary ministry in the city is the communication of the good news.

We have already referred to Grigg's complaint (1987:23) that, whereas mission to the middle class is usually seen in terms of proclamation, the apparent physical and 
existential needs of the poor are so overwhelming that the ministry to them is often limited to giving handouts or assisting in their "development", sometimes without any thought about the proclamation of the good news to them. He rightly calls the church back to its most basic task. Whatever we may be saying about service, diaconal involvement and the like, it must not for one moment be forgotten that what makes the church's contribution in this area unique and irreplaceable is the gospel that is communicated in and through these actions.

There are ample strategic reasons for missions to give renewed attention to the cities.

* Firstly, history seems to be moving in the direction of the city. Whether we like it or not, the cities of the world are increasingly becoming the power centres. This is already a good enough reason to target the cities with the gospel.

- Secondly, the unreached peoples of the world are moving to the cities. This is a new frontier for mission. Never before were the unreached so reachable.

* It is also true that the migrants to the city "are the largest, most responsive group on earth today" (Grigg, 1987:13). Church growth research has demonstrated convincingly that people are most open for religious change when they are in periods of uncertainty because of a situation of flux. If you are looking for responsive people, says Greenway, "when the streets are paved, move on"! It is found that the first five years following a person's or a family's migration is the time of greatest responsiveness to the gospel. It would be unforgivable if the church fails such people by effectively withholding from them the gospel at such a time of need.

\section{Diakonia}

The second dimension will be selfless diaconal service to the people of the city.

The "vertical" mission of proclamation should find a complement in "horizontal" service ministry. None of these can be omitted, although in practice it is quite difficult to keep them in balance. We already indicated the needs of the new city dwellers as the point of entrance. There should however not be any thought of capitalising on the desperate situation of poor people in order to gain entrance. What is at stake is the whole gospel, a holistic ministry. The needs of the complete human being - as we have seen above - must be met with the whole gospel.

"Neither a deed-only nor a word-only strategy is at all adequate in the city", says Greenway (1989a:15), who gives five principles for an urban diaconate: 
a. "The goal of all Christian ministry in the city is that God receives glory through the salvation of sinners, the building of the church, and the extention of his Kingdom ..."

b. "Central to the task of the church in the city is the proclamation of the gospel ... This task never competes with diaconal ministry, but accompanies it, complements it, and becomes the driving force ..."

c. "(It) begins with the poor among believers, for they are the church's first responsibility (Gal. 6:10). But it does not end with them ..."

d. "Diaconal evangelism in the city is a natural outcome of a biblical understanding of the breadth of human needs and God's provisions in Christ ..."

e. "(Urban diaconate) must be (w)holistic, going beyond relief and temporary cosmetics to treating the long-range causes of poverty and their resulting conditions ... political involvement cannot be ruled out ..."

In South Africa this would mean - among other things - that the structural problems which were indicated above (such as the housing shortage, home ownership, the legitimacy of the decision making, the constraints on freedom of movement, the franchise, etc.) should also be addressed by the church. It would not be enough to render short term, compassionate service, but the long term solutions to these (political and economic) problems should be sought and negotiated.

It would also mean that the church of the not-so-poor should build significant relations with the church of the poor in order to search for true mutuality in service.

Most certainly the goal of all mission is the glorificatio et manifestatio gratia divinae. But what is expected in the unfortunate people? In essence the goal of the diaconal involvement can be formulated as follows:

To return self-respect to the poor. To fashion pcople of pride and dignity from people who have been used and tossed aside. To free people from their bondage - in the name of Christ!" (Linthicum, 1989:10)

\section{Koinoniá}

The almost impossible balance between proclamation and service can only be reached when we also emphasise the third dimension, namely the churh as koinonia-community.

As with Jesus, who fulfilled his holistic ministry only in communion with his disciples 
and the Father, so the establishment and exemplary community life of the church is the key to mission in the city.

The church of the (relatively) rich - the suburban church - is in great need. As elsewhere, the suburban church in South Africa needs to be challenged in the light of its almost ideological self-suffiency. The promises of peace and stability, guarantees of high living standards, the retention of law and order, these seem to have become the elements of a new ideology encapsulating the comfortable church in a "laager mentality", and closing the door for sacrificial ministry in the whole city. It is such a church that causes the credibility gap in the politicised and polarised world of today. The church itself could even be the stumbling block for real mission in the city. There is still much work to be done in the church!

But the church of the poor exists among the urban masses. This church may hold the key to the future ministry in the city. Today, these churches among the urban poor who are serving them and helping them organise, are the ones who are showing vitality and growth. Poor, simple churches are today succeeding in enabling the poor and powerless to take responsibility for their own situation and destiny.

The key question remaining, after having established the truth that the local church is the key, is that of the relationship between this local church and other organisations. What role can outside Christians, churches and organisations play in this kind of liberating ministry to the cities?

Linthicum (1989:9) gives a first answer:

\footnotetext{
"An outside agency can help these community organizations financially, or it can train leaders, provide technical support or start projects. But only after these communities have determined for themselves how to achieve self-sufficiency."
}

The local communities will have to decide for themselves whether or not they wish to have support and what kind of support they would appreciate. The time of large scale, almost imperialistic, programmes are past. And when people from the outside do get involved, they would have to follow the incarnational "body" model by becoming part of the local body life and work towards the health of that body.

Of fundamental importance is the vision of the unity of the church. The koinoniadimension should lead the church in all its local and organised forms to reconsider its relations to the rest of the body. It may be here where the church will fail - or help save - the city. 
The phenomenon of the city is impressive, the process of urbanisation is one of the central features of our time, and ministry of God's people in the cities one of the great challenges of the future. May the church not be found wanting as God's witness.

The cilyscape is not a dismal grey, but for the Christian, a panorama of colour and possibility ... the city, too, is God's (urf" (Rubingh, 1987:379).

\section{BIBIOGRAPHY}

BAKKE, R.J. 1984. Urban evangelization: a Lausanne strategy since 1980. Intemational Bulletin of Missionary Research, 8(4): 149-154.

BARRETT, D.B. 1986. World-class citics and world evangelization. Birmingham : Ncw Hope.

BARRETT, D.B. 1988. Living in the world of AD 2000 . World Evangelization, 11-14, Nov. - Dec.

BERNSTEIN, ANN 1989. Focus on the cities. Towards a new national agenda. Africa Insight, 19(2): 6571.

CONN, H.M. 1984. The rural/urban myth and world mission. Reformed World, 37(3): 125-163.

CONN, H.M. 1985a. In the city I'm a number, not a person. The depersonalization misunderstanding, Uhan Mission, 2(5): 6-19, May.

CONN, H.M. 1985b. Lucan perspectives and the city. Missiology: an intemational neview, 13(4): 409-428, Oct.

CONN, H.M. 1986. Any faith dies in the city. The secularization myth. Urban Mission, 3(5), May.

COOPER, CAROLE c.a 1989. Race Relations Survey 1987/88. Johannesburg : SAIRR.

DE BEER, F. 1989. Informal settlements in Africa cities. Africa Insight, 19(2): 72-81.

DEWAR, D., TODES, D. \& WATSON, V. 1984. Urbanization processes and policies in Africa: lessons from Kenya, Tanzania, Zambia and Zimbabwe. Joumal of Contemporary African Studies, 3(1/2): 79-107, Oct 1983 - Apr. 1984.

ELLISON, G.W. 1987. Addressing fell needs of urban dwellers. Uthan Mission, 4(4): 26-41, March.

FAIR, R.J.D. 1985. The urbanisation process in South Africa. RSA 2000, 7(1): 1-6.

GREENWAY, R.S. 1989). Christian responses to the urban poor. Missionary Mfonthly, $96(1026)$ : 13-16, Jan.

GRIGG, V. 1987. Sorry! The frontier moved. Uthan Mission, 4(4): 12-25, March.

HENNING, H. 1989. Housing demands outpace SA capabilitics. Cross Times, 13, Jan.

LANGE, J. 1979. Die invloed van dic Rickert-verslag op dic ckonomiese rasionaliteit van weltige en onwellige migrasie van Swart werksoekers na Blanke stede. (In Lange \& Van Wyk reds. Implikasies van die Rickert-Verslag. Pretoria : Unisa. p.127-143.)

LINTHICUM, R. 1989. Seduced by the city. World Vision, 33(3): 5-10, Jun.-Jul.

MASHILE, G.G. 1985. Contained urbanisation in South Africa. RSA 2000, 7(1): 80-83.

MONSMA, T.M. 1989. Urbanization now and at the turn of the millennium. World Evangelization : 28 30, March-April.

RUBINGH, E. 1987. Mission in an urban world. Evangelical Review of Theolog\%, 11(4): 369-379, Oat.

SIMKINS, C. 1985. Projecting African population distribution and migration to the ycar 2000. RSA 2000 7(1): 41-46. 
